University of Nebraska - Lincoln

DigitalCommons@University of Nebraska - Lincoln

University of Nebraska Press -- Sample Books

and Chapters

University of Nebraska Press

2012

Yuchi Indian Histories Before the Removal Era

Jason Baird Jackson

Follow this and additional works at: https://digitalcommons.unl.edu/unpresssamples

Part of the Arts and Humanities Commons

Jackson, Jason Baird, "Yuchi Indian Histories Before the Removal Era" (2012). University of Nebraska

Press -- Sample Books and Chapters. 125.

https://digitalcommons.unl.edu/unpresssamples/125

This Article is brought to you for free and open access by the University of Nebraska Press at DigitalCommons@University of Nebraska - Lincoln. It has been accepted for inclusion in University of Nebraska Press -- Sample Books and Chapters by an authorized administrator of DigitalCommons@University of Nebraska - Lincoln. 


\section{Yuchi Indian \\ Histories \\ Before the \\ Removal Era}


Yuchi Indian Histories Before the

\section{Removal Era}

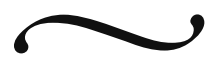

Edited and with an introduction by

JASON BAIRD JACKSON

University of Nebraska Press Lincoln \& London 
(C) 2012 by the Board of Regents of the University of Nebraska All rights reserved. Manufactured in the United States of America @

Library of Congress Cataloging-in-Publication Data

Yuchi Indian histories before the removal era / edited and with an introduction by Jason Baird Jackson.

p. $\mathrm{cm}$.

Includes bibliographical references and index. ISBN 978-0-8032-404I-4 (pbk.: alk. paper)

I. Yuchi Indians-History. 2. Yuchi Indians-Social conditions. 3. Yuchi Indians-Social life and customs.

I. Jackson, Jason Baird, I969-

E99.Y9Y83 $20 \mathrm{I} 2$

$305.897^{\prime} 9-\mathrm{dc} 23$

2012006240

Set in Sabon by Bob Reitz. 


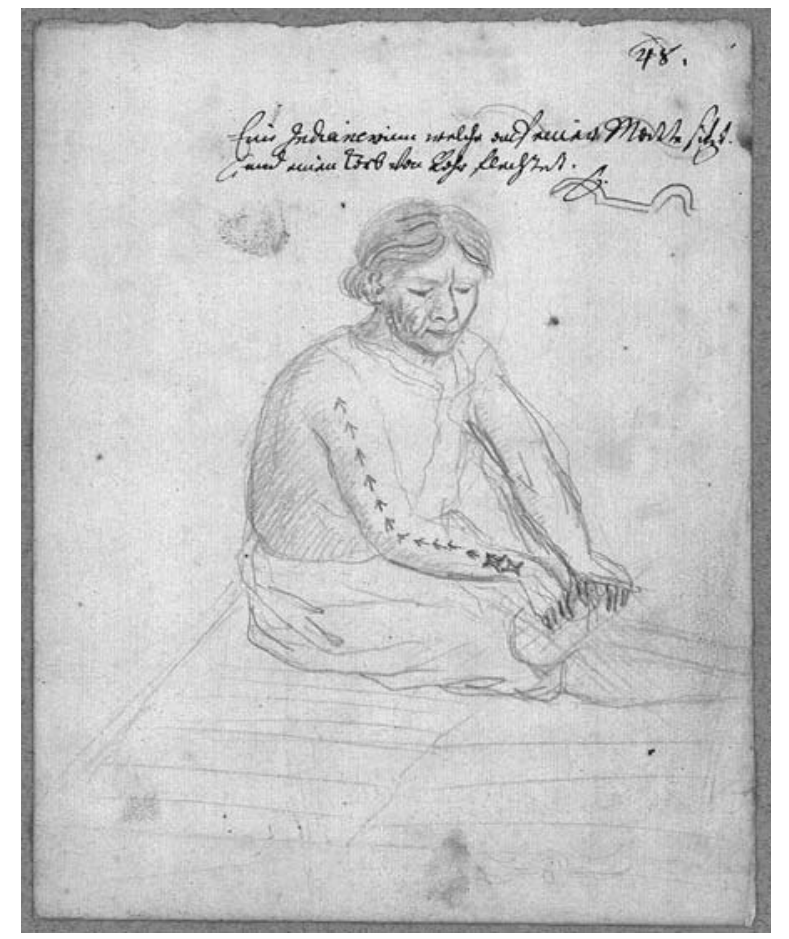

FIGURE I. "An Indian woman weaving a basket of reed." Pictured on the colonial frontier of Georgia in I73 6 by Philip Georg Friedrich von Reck or someone in his retinue. NKS $5654^{\circ}$ (Von Reck's drawings), No. 48. The Royal Library, Copenhagen, Denmark.

For discussion of this image and the collection from which it comes, see Hvidt, Von Reck's Voyage, II 2-I3. The image is online at http://www.kb.dk/permalink/ 2006/manus/22/eng/No.+48/?var=.

Dedicated to the Yuchi women whose long labors across five centuries-while barely observed by the colonial recorders whose experiences inform this volume-have helped insure a bright future for their people.

For the support of its historical preservation efforts, the Euchee (Yuchi) Tribe of Indians has been named as the direct beneficiary of any author royalties generated through the sale of this volume. 


\section{Contents}

\section{$\sim$}

List of Illustrations . . ix

List of Maps .. $\mathrm{x}$

List of Tables .. xi

Introduction:

On Studying Yuchi History . . xiii

JASON BAIRD JACKSON

I. Deep Time and Genetic Relationships:

Yuchi Linguistic History Revisited . . I

MARY S. LINN

2. Enigmatic Origins:

On the Yuchi of the Contact Era . . 33

JOHN E. WORTH

3. Reconsidering Chestowee:

The I713 Raid in Regional Perspective . 43

BRETT RIGGS

4. Yuchi in the Lower Savannah River Valley:

Historical Context and Archaeological

Confirmation . . 73

DANIEL T. ELLIOTT 
5. The Yuchi Indians along the Chattahoochee and Flint Rivers (I7I5-I836):

A Synthesis .. IOI

H. THOMAS FOSTER II

6. "They Look upon the Yuchis as Their Vassals":

An Early History of Yuchi-Creek

Political Relations .. I23

STEVEN C. HAHN

7. Reconsidering Coalescence:

Yuchi and Shawnee Survival Strategies in

the Colonial Southeast.. I55

STEPHEN WARREN

8. To the Backcountry and Back Again:

The Yuchi's Search for Stability in the Eighteenth-

Century Southeast . . I89

JOSHUA PIKER

9. A Band of Outsiders:

Yuchi Identity among the Nineteenth-

Century Florida Seminoles . . 2 I5

BRENT R. WEISMAN

List of Contributors . . 233

Index . . 235 


\section{List of Illustrations}

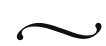

I. "An Indian woman weaving a basket of reed" .. v

2. "War Dance" . . 78

3. Yuchi pottery sherds . . 85

4. "Indians going a-hunting" . . I6I

5. A French copy of a Chickasaw/Alabama map of I737 . I I93

6. Timpoochee Barnard as pictured around I825 . 203

7. Stone memorial commemorating John Winfield

Scott McNeil . 2 2 6

8. Tuko-See-Mathla, aka John Hicks . . 222 


\section{List of Maps}

I. The Yuchi and their neighbors (I566-I568) . . 38

2. Towns and settlement areas discussed in this chapter . . 46

3. Mount Pleasant Yuchi Town and related settlements . 74

4. Yuchi Mount Pleasant village plan . . 83

5. Location of Yuchi Town (I7I5-I836), Chattahoochee River, Alabama .. I04

6. Yuchi daughter settlements, Chattahoochee and Flint River watersheds (I7I5-I836) . . II5 


\section{Tables}

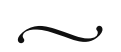

I. Yuchi verb template . 6

2. Sapir's Eastern Group, I92I and I925 .. I4

3. Sapir's Eastern Group, I929 . . I4

4. Summary of aboriginal pottery, Mount

Pleasant, Georgia . . 87

5. Species list from two seasons of test excavations at Trader

Point Excavations, 9EFI69 . .88

6. Artifact pattern at Mount Pleasant . 90 


\section{Introduction \\ On Studying Yuchi History}

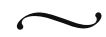

The Yuchi (alternatively Euchee) are a native North American people with a compelling story to tell. Yuchi people today, in the twenty-first century, still speak their own unique indigenous language, one unrelated to any known language of the Americas. While many Yuchi people are proud of their non-Yuchi ancestors just as they are proud of their Yuchi ones, there are today Yuchi people who know themselves to be-in the unfortunate language of U.S. Indian policy - "full-blood" Yuchis. The Yuchi people are led today, as in times past, by hereditary chiefs who govern towns that are both autonomous sociopolitical units and nodes in a broader social network that both constitutes a wider Yuchi society and situates Yuchi people for participation in a regional social system linking them through relations of reciprocity and exchange with indigenous communities stretching from the Iroquois longhouses of Canada to the dance grounds and chickee camps of the Florida Seminoles. The Yuchi people have not only survived the terrors of the past five hundred years; they enter the second decade of the twenty-first century as a thriving people. That is all story enough, but the narrative gets strange. The vital people whom I have just described have been characterized in some authoritative published works as extinct, and despite having all the hallmarks associated with such status, they 
are unrecognized in every way that counts by the federal government of the United States and by the Muscogee (Creek) Nation, the Native American polity that possesses the authority to speak and act on their behalf in contemporary formal and legal contexts. For some observers, the Yuchi do not exist; for others they are not supposed to. The chapters gathered in this volume aim to advance the project of making sense of how these two stories - persistence and marginalization - are braided together and rooted in the wider story of what happened to the Yuchis and other indigenous peoples in the years that followed the arrival of European and African peoples in eastern North America. The chapters gathered here are resolutely provisional and occasionally contradictory. They represent our best efforts at starting work that needs to be pursued more vigorously, carefully, and systematically than has been possible so far. They are a start.

While Yuchi individuals live today throughout the United States, the Yuchi people whose history is the focus of this modest volume can be found living in distinct and distinctive communities in what are today Creek, Tulsa, and Okmulgee Counties in east-central Oklahoma. ${ }^{1}$ For modern Yuchis today, these contiguous town communities, which together are thought of as Yuchi country, represent home. But Yuchis are also quite aware that Oklahoma is not the old country from which their ancestors were forced by the government of the United States in the I83os. Living on the South's northwestern margins, Yuchi families today preserve oral traditions of the hardships endured during removal, and these stories provide a link to a deeper past and to eastward places that many Yuchis hope to have a chance to visit - the Savannah, Flint, and Chattahoochee River Valleys in present-day Georgia and Alabama; the Appalachian Mountains of Virginia, Tennessee, and the Carolinias; the pine woods and swamps of Florida. ${ }^{2}$ As the contributors to this volume begin to reveal, these places, like eastern Oklahoma, are places where Yuchi people were actors not only in their own histories but also in those of other much better known Native peoples and of the European colonizers and forcefully dislocated peoples of African 
ancestry with whom all Native peoples of eastern North America peoples have had to contend since the sixteenth century.

In the surviving documents from which histories of eastern North America after European colonization can be and have been written, there appear the names of hundreds of Native American communities. About some of these groups we now know quite a lot, but for most, little knowledge is available to us. Scores of Native peoples who once possessed distinctive identities and ways of life that represented unique local configurations of regionally distributed practices and beliefs were destroyed through the combination of introduced diseases, enslavement, military conquest, and the social disruption wrought by European colonization. Other peoples, more fortunate, found a range of creative ways of coping with these devastating disruptions. Some moved vast distances seeking new locales better positioned to enable them to survive and, ideally, thrive in the context of social change. Some radically altered their ancestral ways of life to develop new strategies more attuned to life in colonial contexts. Some entered into confederation with former neighbors - and sometimes former enemies - so as to create viable new societies better adapted to a new era. In a dynamic social process, some peoples sought refuge among neighbors. When this happened, sometimes they assimilated the languages, cultures, and social customs of their more powerful hosts. In other instances, recognizably distinct and new peoples emerged through the process known as ethnogenesis, wherein diverse source communities combine to create a new society with a hybrid or creolized culture and, often, novel social arrangements. The contributors to this volume share an interest in the diversity of ways that the Native peoples of eastern North America sought to position themselves in the stream of history after contact with Europe. Here, the almost completely unexamined case of the Yuchi people provides a productive vantage point on these broader questions. ${ }^{3}$

In a phrase that resonates with the whole problematic of this volume, then newly arrived German colonist Johann Bolzius, writing of colonial Georgia in 1734 , commented: "One of the other nations, 
who are called Uchees, are much inclined to robbing and stealing, but these Creeks are honest, serviceable and disinterested."4 It would seem that such "othering" opinions, offered parenthetically in published accounts largely concerned with "other" matters, are almost all that we yet have by way of Yuchi history before removal. Long an obvious need, the near complete absence of reliable, published work on Yuchi history has now become an obstacle, both to contemporary Yuchi community interests and to the growing and ever richer scholarly literatures on the Native Southeast, the American South, and the history of eastern North America more generally. By drawing together scholars from a range of fields whose research has intersected with Yuchi matters, the goal of this volume is to locate Yuchi history in space and time, in preliminary fashion, thereby fostering what might eventually become a robust Yuchi national historiography. In advancing such a goal, I am grateful for the contributors' willingness to take time away from other projects - projects more central to their long-term scholarly careers - to participate in this undertaking. We all share the hope that the work gathered here will serve as a starting point, and perhaps also an inspiration, for a more sustained and comprehensive study of Yuchi history in all its dimensions, eventually including consideration of cultural, social, economic, political, and other questions. The Euchee (Yuchi) Tribe of Indians, the contemporary community organization representing pan-Yuchi interests, is also very eager to promote such studies, as evidenced by its own recent work compiling sources on tribal history, its sponsoring of a Yuchi history symposium in 2010 at which several of the contributors to this volume presented their work, and its endorsement of the project that has resulted in this collection.

\section{Other Work to Do}

That the Yuchi have received so little historical attention is a complex puzzle in light of the considerable amount of sophisticated effort that has now been devoted to historical studies of Native, colonial, and early American history in the American South and the wider Atlantic world. In the course of their investigations, the authors 
represented in this volume suggest some of the factors that have contributed to this neglect-a limited but daunting corpus of historical sources, long-standing misunderstandings propagated in early and foundational scholarship, confusion over synonymy (i.e., ethnic group names), and an overreliance on certain typological models of Native societies (e.g., chiefdom, confederacy, nation, tribe) and of social change within them (e.g., coalescence, ethnogenesis, colonization). While much of the best work being done in this field is strongly multidisciplinary in orientation, a great deal of research continues to be pursued in isolation by historians and archaeologists working separately, and there have been too few cultural anthropologists, linguists, human geographers, and folklorists available and interested to participate in the broader project of writing the social and cultural history of the region. Bringing the work of a varied group of scholars together here is a further nod in the direction of cross-disciplinary work, but given its particular challenges, a bona fide project focused on Yuchi history (as one pressing example) will require a more integrated and collaborative approach. Such work remains the incompletely fulfilled promise of the interdisciplinary field of ethnohistory. ${ }^{5}$

To the extent that the Yuchi people have appeared in the annals of history over the long haul, they have done so as bit players in other peoples' dramas. The contemporary Yuchi community and the contributors to this volume would all be quick to acknowledge the ways that the Yuchi have always been well networked. In criticizing the marginalization of the Yuchi people in the extant histories, I am not advocating a view that would move them to the center of the frame without attending to their linkages to other peoples. My work as an ethnographer and ethnologist is aimed at understanding Yuchi cultural practices and social relations within a wider regional frame that accounts for the ways in which Yuchi social ties (some persistent, some changing) to other groups play a role in sustaining the distinctive configuration of both unique and more widely shared elements that Yuchi people understand as their traditional culture. ${ }^{6}$ The problem has not been understanding Yuchi history 
vis-à-vis the histories of other peoples; the problem has been inattentiveness to the positioning of the Yuchi within such histories. Put more simply, sources on Yuchi history have either misrepresented them as no longer existing as a people (and thus as either completely extinct or as fully assimilated, culturally and socially, into a homogenized Muscogee [Creek] Nation) or have been built uncritically upon the biases of sources, particularly elite Muscogee nationalists but also colonial observers, who have sought in their words and actions to subjugate Yuchi autonomy to advance personal agendas and Muscogee national (or colonial) projects.

The preceding Bolzius quotation serves two useful purposes in the present context. It is advantageous in that it is a useful reminder that non-Yuchi observers sometimes did acknowledge the Yuchi, not only as the autonomous and distinctive people that both the contemporary Yuchi community and past generations of Yuchi people understood themselves to be but, going further, as a "nation" alongside and distinct from the Creek nation and other native societies. ${ }^{7}$ It is useful, if also disheartening to Yuchis and their friends, in that it - in the space of a sentence-stands as an illustrative token of the type of anti-Yuchi discourse that has dominated their treatment in historical works colored by elite Creek narratives and a scholarly preoccupation with the careers in time of the so-called five major Indian Nations - Creek, Cherokee, Choctaw, Chickasaw, and Seminole - to the neglect of the dizzying diversity that did, and still does, characterize the lived realities of American Indian peoples in the South and in eastern North America more broadly. As the contributors to this volume suggest, the colonial South was a place where the honesty, serviceablity, and disinterested status of individuals and groups - as well as robbing and stealing - were very much part of the human experience, but these characteristics hardly mapped neatly onto bounded societies easily understood as uncontested nations. In the historical literature, unsympathetic descriptions of the Yuchi people (what Joshua Piker characterizes in his chapter as the "Yuchis are thieves" narrative) have been easier to locate than more nuanced or charitable ones. The authors of the essays gathered here 


\section{Introduction}

have made important efforts to find and deploy sources that offer a richer picture even as some of them have faced the challenge of making sense of this historically dominant discourse. ${ }^{8}$

The most famous dissent to such opinions documented for the preremoval era is that offered by the naturalist and proto-ethnographer William Bartram in his Travels. Bartram was favorably impressed with the Yuchi town on the Chattahoochee River, which he visited in summer $\mathrm{I} 775$, describing it as the "largest, most compact and best situated Indian town I ever saw" with homes that were "large and neatly built." The town plan and domestic architecture that so impressed Bartram were home to a community that struck him as "populous and thriving, full of youth and young children." He understood the town's population of $\mathrm{I}, 000-\mathrm{I}, 500$ citizens to be capable of mustering "five hundred gun-men, or warriors." Despite the brevity of his encounter with the Yuchi and the uncertainty that he, and we, experience in characterizing Creek-Yuchi relations, Bartram was at pains to note his awareness of the manner in which the $\mathrm{Yu}-$ chi were typically on the receiving end of Muscogee (Creek) "jealousy," how the Yuchi "do not mix with" their Creek neighbors, and how the Yuchi were "usually at variance" with them. ${ }^{9}$

I am an ethnographer rather than a historian, and this experience colors my concerns and reactions to the state of Yuchi historiography. More obviously, my rich personal relationships with the Yuchi people of today motivate me to promote the view that scholars can do better than simply recount the slander of those period elites who brought their own biases and agendas - often hegemonic - to their accounts of and dealings with the Yuchi people. Focused as they are on the present and the recent past, my previous writings on Yuchi topics add little to the historical discussion, but my hope is that they provide some motivation for new scholarly work on Yuchi history. ${ }^{10}$ In a simple sense, I hope that my ethnographic work at least serves as a corrective to views such as those recycled in many secondary sources. I am close enough to contemporary Yuchi people to know something of what it is like for them to live in a world still shaped by such talk. I also know that there are today still Creek elites who 
speak and think of the Yuchi in this way. ${ }^{11}$ My point is not to criticize past scholars, although I wish they had been more nuanced, given the long shelf life that scholarly writings on little-known peoples typically enjoy. My purpose instead is to evoke a set of research problems that, while they are perhaps obvious, have remained unexamined and that - given the recent advances made by students of Creek history on the one hand and of Yuchi ethnography on the other - are more and more blatantly in need of attention.

At a minimum, some future student of Yuchi or Muscogee (Creek) history could tackle, in more systematic fashion, the problem of Creek and European perceptions of the Yuchi through time. Accessible sources obviously exist and the exercise would prove very helpful. This venture would generate more important follow-up questions, such as assessing continuity and change through time and grappling with the motivations that might underlie these pronouncements.

Stepping back to survey bigger problems, the disdain found in primary and secondary sources makes clear that despite recent advances, we still do not quite know how to characterize the changing social landscape of the Native Southeast. Perhaps we are almost there, but our new and more complex models of Creek country through time still reduce the Yuchi to footnote status and presume their assimilation into what was, and is, an essentially Creek cultural, political, and economic system. Despite noting Creek cultural heterogeneity, the current tendency is still to treat the Yuchi as structurally equivalent with Nuyaka, Coweta, or some other Creek italwa (tribal town). I have previously attributed this to the lack of readily accessible historical data, but I am increasingly convinced that such views are largely the residue of past conventional wisdoms that have not yet been completely scrutinized through fresh research. ${ }^{12}$ Even if the contemporary Yuchi community was not doing everything possible to proclaim its continued existence as a distinct people with a unique language, a characteristic culture, and their own understanding of both their past and their relationship to Creek people, how could scholars, when presented with the chronicle of disdain conveyed by Creek and European elites, go on writing, and not writing, of the 
Yuchi in history, as we have been doing? The contributors to this volume make important contributions aimed at turning this tide.

The broader interests of anthropology and history are today centered, in part at least, on what we might broadly characterize as narratives of resistance. I can think of no surviving Native North American people who better epitomize successful resistance, or to phrase it more positively, successful persistence, than the Yuchi. ${ }^{13}$ While each of this volume's contributors seeks to make a contribution to a provisional telling of Yuchi history before removal, all of us would welcome someone taking up this work in a fulltime way. Speaking in the most instrumental terms, the next new book on a topic in pre-removal Creek or Cherokee history will certainly find interested readers in a growing community of scholars and students concerned with the history of the Native South, but some talented researcher still has the opportunity to complete the first book-length contribution on Yuchi history. ${ }^{14}$ The present volume is intended, in part, to help clear the way for such an undertaking. I am confident that each of its contributors would welcome the chance to assist scholars interested in contributing to such work. If, despite my reservations, such a researcher must begin with the assumption that the Yuchi of, say, Benjamin Hawkins's day were just another township in Creek country, so be it. One has, in Joshua Piker's fine book on Okfuskee, an up-to-date model for researching a town-centered social history. ${ }^{15}$ I hope all the contributors to this volume can offer further resources for such a project. Best of all, a modest and diligent historian willing to undertake serious work on Yuchi history will gain engaged allies among the Yuchi people. Yuchi interest in historical research stems from many sources, from the genealogist's impulse to understand one's personal past better to the politician's need to understand how the Yuchi came to be so disempowered, even by the standards found in Indian country. Contact with the generous Yuchi community of today will certainly raise suspicions about how their ancestors have been portrayed.

What modest progress that has been made recently, with respect to Yuchi history, has largely taken the form of corrective notes and 
a broader dismantling of provisional hypotheses that had, in light of John Swanton's scholarly prominence, become accepted interpretations. ${ }^{16}$ Because Verner Crane and Swanton published their debate on Yuchi-Westo affiliations, scholars, faced with uncertainty, have traditionally approached this linkage more cautiously. John T. Juricek productively examined the Westo problems in the early I960s, and more recently Eric Bowne has been pursuing new Westo work allowing us to tackle other thorny problems of synonymy and social history. ${ }^{17}$ Most influential and problematic among these is Swanton's linkage of the Yuchi with the people known in colonial-era sources as the Chisca.

This matter is especially embarrassing for me, as Amos Wright's Historic Indian Towns in Alabama, I540-1838 was not the only book published in 2003 that almost certainly erred in accepting Swanton's long-standing Chisca proposals. Despite the fears expressed in the endnote buried on its page 29I, I proceeded in Yuchi Ceremonial Life as if this linkage were firm. ${ }^{18}$ No sooner was the book fixed in type than John Worth provided a convincing analysis suggesting that this is not so. My only consolation comes in noting that a Bancroft Prize-winning author can commit the same error that I did. Like me, Alan Gallay reproduced almost the whole of Swanton's rickety Chisca-Yuchi analysis, although to his credit, he did so while laying the groundwork for a useful account of a crucial event in Yuchi history, the destruction of Chestowee town in I7I $4 \cdot{ }^{19}$ Over the decades, countless scholars of note have built complex narratives atop Swanton's Chisca-Yuchi proposal, thereby confusing the literature and associating the Yuchi with unpleasantness in which they likely had no hand.

In the Southeast volume of the Handbook of North American Indians, Worth offers an account of the Chisca that contains a summary of his position on this matter. Thirty-four years in the making, this long forsaken tome saw the light of day only in 2004. While the Handbook is now available for consultation, I think the present volume can be strengthened by reiterating Worth's Chisca findings here, especially as they relate to his chapter in this volume directly 


\section{Introduction}

and, generally, to the subject of the volume as a whole. After sketching what is known of the Chisca (I preserve his parenthetical citations), he notes:

Though some authors have equated the Chisca with both the Yuchi and the Westo (or Chichimeco) Indians (e.g. Swanton 1922:288308; Hann I988:78-79, I996:238-40), [recent] ethnohistorical work suggests that all three groups were distinct (Worth I995a:52, 54; I998:208). The Yuchi were noted separately from the Chisca under the names Uchi and Huchi during the Juan Pardo expedition in I567, both being part of an anti-Spanish plot hatched by allies of the paramount chief of Coosa in the Ridge and Valley district west of the Appalachian summit (Hudson I990:223-24, 270). Furthermore both French and English sources report Yuchis still in the Tennessee River valley in the early eighteenth century, their last town there being destroyed by Cherokees in I7I4 (Bauxar 1957:389-96, 433-34; McDowell 1955:24, 53-57), and it was only a little before that time that Yuchis first migrated into the Savannah River valley and among the Lower Creeks of western Georgia (Worth 2000:285; "Yuchi," this volume). The Westo Indians, who invaded Guale province in I66I, have now been demonstrated to be a band of immigrant Erie Indians who slaved for the Virginians after I659 (Swanton I922:305; Worth I995a:I5-I8; B. G. Hoffman I964; W. Greene I998; Bowne 2000). ${ }^{20}$

The good news in all this is that having grappled with the Chisca, Worth is now in a position, as indicated by his contribution to this volume, to confront the data, both historical and archaeological, that might tell us something positive about the "Uchi" themselves during the early contact period.

\section{The Earliest Yuchi History}

To the extent that the complexities of pre-removal Yuchi history in time and space can be arrayed in linear fashion, this volume proceeds in a roughly chronological order, beginning with Mary S. Linn's work on the linguistic affiliation of Yuchi and its implications for 
social and cultural history. We can hope that historical linguistics and archaeology will offer new insights into the Yuchi story before contact and that historians and historical archaeologists will find ways to enrich our knowledge of the period since. In my experience, Yuchi people have a high level of interest in the possibilities of such new research. They would welcome the discovery of new sources and would listen to new interpretations with great interest. While Linn's contribution reaches back to consider the time before European colonization of the Southeast, the remaining contributors to this volume present findings related to the period from the contact era through the removal era, which in the case of the Florida Seminoles considered by Brent Weisman comes to a close at a later period than for some other southeastern Indian peoples. ${ }^{21}$

While Yuchi people have conveyed great interest in the possibility of academic histories of their people, they also possess stories that scholars should listen to if such work is to proceed in the most fruitful fashion. It is historically paradoxical, but culturally quite reasonable, that the history Yuchi narrators know best is the oldest Yuchi story, the history of their creation as a people. In concluding this introduction and beginning the volume's work in earnest, I wish to summarize these accounts briefly, and I conclude with some observations on their relevance to our purposes.

As Yuchi elders past and present have described it, in the time of creation, Tsoyaha, the child of the Sun and Moon, sprang from celestial blood to become the first Yuchi man. At the heavenly square ground, which we of this world see as the rainbow, he was taught the most basic tribal rituals - purification through scratching, fasting, and the consumption of redroot and snakeroot medicines. To cure his loneliness, his mother removed one of his ribs, from which his wife was fashioned. When they then established the Yuchi people in this world, he was instructed to pass on these rites - the rituals of the Green Corn Ceremony. Today these powerful, complex, beautiful ceremonies remain the central defining force of distinctly Yuchi life today. Later in ancestral time, additional aspects of their patrimony were revealed to the Yuchi. Oral history thus recounts 
the revelation of Cedar and Tobacco as additional sacred medicines, the bestowal by the White Crane of the Feather Dance songs, and the tragic but ultimately heroic and instructive origins of the Lizard Dance. In dramatic form, the Green Corn Ceremony enacts this ancient history and maintains it as a vital force in contemporary Yuchi life. ${ }^{22}$

It is beyond the scope of this volume to say more about the narratives that Yuchi historians and cosmologists continue to recount and that the three modern Yuchi towns enact in ritual. For our purposes, it is enough to note that these histories not only provide a warrant for Yuchi peoplehood - they also charter the possibility for the contributors to undertake historical work seeking to disentangle the Yuchi from the Creek and colonial narratives in which they have become caught. Yuchi tradition acknowledges the quite separate origin stories possessed by the Muskogean peoples, stories not of a descent from the heavens but of an emergence from a primordial underworld. ${ }^{23}$ There is no reason to presume that these different origin narratives are modern fabrications. At the very least, they reflect what eighteenth-century sources knew, that the Yuchi and Creek are quite different peoples. In the present I would similarly note what Lester Robbins first observed in his early I970s Creek fieldwork. No so-called Lower Creek town today preserves its Green Corn Ceremony, while their neighbors the Yuchi remain devoted to the ceremonies of their own towns. ${ }^{24}$ According to Yuchi customary belief, it is a good thing for non-Yuchis that they do, as the Sun looks down each day to see if his or her children remain in this world. Similarly, each summer the Sun observes the Yuchi Green Corn Ceremonies. When the Yuchi are no longer here, or when they no longer perform the ceremonies with which they were entrusted, the end time will come and everyone and everything will perish. ${ }^{25}$

Just as modern Yuchis do not deny the relevance of their Creek neighbors and kinspeople to their own lives, I am not proposing that we ignore the place of the Yuchis in Creek history or vice versa. As an ethnographer, rather than a historian, I am only suggesting that the ongoing persistence of cultural difference and social separation, 
coupled with patterns of social differentiation rather than straightforward incorporation, suggest to me that we can do better in accounting for the Yuchi past before, during, and after the time of their encompassment by their more numerous and at times domineering neighbors. So far the story has been a default one in which progressive assimilation into an ever more homogeneous Creek society has been presumed. While the archaeological record has pointed to commonalities in material life, Yuchi tradition and post-removal ethnography suggest that there may be other stories to tell. This book is a step toward such an investigation.

\section{Acknowledgments}

I wish to record my deep appreciation to the officers of the Euchee (Yuchi) Tribe of Indians, including the Yuchi town chiefs, for their support of this and related projects. Thanks are due as well to the staff of the University of Nebraska Press for its constant support of this book. I am particularly appreciative of the volume's authors for their valuable contributions. They, along with the engaged reviewers selected by the press, and the wider circle of "friends of Yuchi history" - including Pamela Wallace, John T. Juricek, Robbie Ethridge, David Chang, Kathryn E. Holland Braund, and Stephen Martin - have begun a collective project of historical investigation that I hope will flourish in the years ahead. Crucial in all my work is the support of my wife, Amy Jackson.

\section{Notes}

I. A summary of Yuchi history and ethnography is provided in Jason Baird Jackson, "Yuchi," in Handbook of North American Indians, vol. I4: Southeast, ed. Raymond D. Fogelson (Washington DC: Smithsonian Institution, 2004), 415-28.

2. Readers of this introduction and this volume will find a number of characterizations of the regional frames within which Yuchi culture and history can be understood. Arising out of the field of history, there is a contemporary argument that stresses the gains that come with referring to the region most at issue in this book as "the South." Characterizing the Yuchi or the Yamasee or the Chickasaw as Native peoples of the South thereby aligns discussions of 


\section{Introduction}

southern Indian history with broader studies of the American South, a powerful regional construct in the intellectual and cultural history (and historiography) of the United States. This is particularly important because Native societies have been systematically written out of a southern history that is too frequently misframed in biracial (black and white) terms. Thus studies of southern Indian history stand to contribute to, and improve, general historical knowledge of the region as a place that is infinitely more complex than conventional wisdom and conventional historical narratives have described.

This view - quite reasonable in its own terms - suggests that the anthropological cultural area designation "Southeast," which has most often framed discussions of the region's Native peoples, unhelpfully sets them outside the line of southern history and of thinking about the region generally. The argument suggests abandoning the term Southeast in lieu of South. I serve on the editorial board of the journal Native South, the venue in which the case for southern Indian studies has been sustained most clearly, and I am sympathetic to the motivations that prompt this effort. As long as the South is itself treated as a problematic and unstable category that has frequently been essentialized, then I support the cause of working vigorously to situate the story of the region's Native societies within a broader history of the South.

Beyond the inclusion argument though, I am concerned with the ways that cultural areas have been characterized in recent discussions focused on the Indigenous peoples of eastern North America. Building on the account of the southeastern culture area that I authored for the introduction to the Southeast volume of the Handbook of North American Indians (co-authored with Raymond D. Fogelson, Washington DC, 2004), I have drafted an essay — still in manuscript - that explores these issues further. It is beyond the scope of this note to address these issues here. For purposes of this volume it is noted that all the authors whose work is gathered here are, to various degrees, aware of the "South or Southeast" question. Many also pursue their work within a framework attentive to the broader Eastern Woodlands and Atlantic world contexts. While a diversity of regional framings are found in this book, all of the authors share a common concern with situating Yuchi history in wider contexts that include regional patterns and interethnic relations.

3. Key collections reconsidering the transformation of native societies in eastern North American during the colonial period include Marvin Smith, Robbie Franklyn Ethridge, and Charles H. Hudson, eds., The Transformation of the Southeastern Indians, I540-I760 (Jackson Ms: University Press of Mississippi, 2002); Thomas J. Pluckhahn and Robbie Franklyn Ethridge, eds., Light on the Path: The Anthropology and History of the Southeastern Indians (Tuscaloosa: University of Alabama Press, 2006); Charles M. Hudson 
and Carmen Chaves Tesser, eds., The Forgotten Centuries: Indians and Europeans in the American South, I52I-I7O4 (Athens: University of Georgia Press, I994); and Gregory Waselkov, Peter H. Wood, and M. Thomas Hatley, eds., Powhatan's Mantle: Indians in the Colonial Southeast, rev. and expanded ed. (Lincoln: University of Nebraska Press, 2006). Contributions to these volumes, along with much other recent ethnohistorical work, explore confederation, disease-prompted demographic collapse, slavery, assimilation, missionization, and other modalities of social transformation experienced in the region during the colonial period. For the concept of ethnogenesis, see William C. Sturtevant, "Creek into Seminole," in North American Indians in Historical Perspective, ed. Eleanor Burke Leacock and Nancy Oestreich Lurie (New York: Random House, I97I), 92-I28; and Jonathan D. Hill, ed. History, Power, and Identity: Ethnogenesis in the Americas, I492-I992 (Iowa City: University of Iowa Press, I996). The historical anthropology of cultural persistence, a framework that seems particularly suitable to the story of the Yuchi, is found in the work of Edward Spicer. See: Edward H. Spicer, "Persistent Cultural Systems," Science n.s. I74 (I97I): 795-800, and Edward H. Spicer and Rosamond B. Spicer, "The Nations of a State," boundary 2 I9 (I992): 26-48. Many contributors to this volume attend to the ways that the brutal trade in Native slaves transformed the colonial South and the Indigenous peoples who called it or came to call it home. A touchstone work on this question is Robbie Ethridge and Sheri M. Shuck-Hall, eds. Mapping the Mississippian Shatter Zone: The Colonial Indian Slave Trade and Regional Instability in the American South (Lincoln: University of Nebraska Press, 2009). Continuity and change in practices of enslavement in southern Indian country are the focus of a recent study by Christina Snyder, Slavery in Indian Country: The Changing Face of Captivity in Early America (Cambridge MA: Harvard University Press, 2010).

4. Charles Jones, Historical Sketch of Tomo-chi-chi, Mico of the Yamacraws (Albany NY: J. Munsell, I868), 47.

5. One of the great merits of ethnohistory as a conceptual meeting ground linking several disciplines is that it is not understood by practitioners in monolithic terms. Debating the nature of the project is one tradition that energizes the field, and not all contributors to this volume understand the field in the same way. My own orientations have been shaped by my teachers, including two past presidents of the American Society for Ethnohistory (ASE), Raymond D. Fogelson and Raymond J. DeMallie. Their approach to the field is illustrated in their respective presidential addresses: Raymond D. Fogelson, "The Ethnohistory of Events and Non-Events," Ethnohistory 36 (I989): I33-47, and 


\section{Introduction}

Raymond J. DeMallie, “'These Have No Ears': Narrative and the Ethnohistorical Method," Ethnohistory 40 (I993): 515-38. Many of the chapters gathered in this volume were initially presented in a panel focused on Yuchi history held at an ASE meeting in Chicago on 28 October 2004.

6. This the particular aim of several of my works, including Jason Baird Jackson, Yuchi Ceremonial Life: Performance, Meaning, and Tradition in a Contemporary American Indian Community (Lincoln: University of Nebraska Press, 2003); Jason Baird Jackson and Victoria Lindsay Levine, "Singing for Garfish: Music and Woodland Communities in Eastern Oklahoma,” Ethnomusicology 46 (2002): 284-306; Jason Baird Jackson, "East Meets West: On Stomp Dance and Powwow Worlds in Oklahoma," in Powwow, ed. Clyde Ellis, Luke Eric Lassiter, and Gary H. Dunham (Lincoln: University of Nebraska Press, 2005); Gregory A. Waselkov (with Jason Baird Jackson), "Exchange and Interaction since I500," in Handbook of North American Indians, vol. I 4 : Southeast, ed. Raymond D. Fogelson (Washington DC: Smithsonian Institution, 2004), 694-96.

7. As I hope my remarks suggest, my highlighting this colonial characterization of the Yuchi as a nation is not meant to suggest that I understand the category of nation as unchanging or unproblematic. In the fields of cultural anthropology and Native American and Indigenous studies, much important work is being directed at carefully disentangling conceptions of nation vis-àvis Native American and European societies and Native and European social thought. Enriched and critical understandings of the associated notion of sovereignty are central to this work. While present-day Yuchis still speak more often of "Yuchi people," "Yuchi community," and "Yuchi tribe," their own ongoing nation-building project (shaped in part by broader trends in Indian country and by the history being evoked here) is reflected in the fact that contemporary Yuchi people also increasingly speak of the "Yuchi nation." For treatments of nation and sovereignty in the Native South, see Circe Sturm, Blood Politics: Race, Culture, and Identity in the Cherokee Nation of Oklahoma (Berkeley: University of California Press, 2002); Jessica Cattelino, High Stakes: Florida Seminole Gaming and Sovereignty (Durham NC: Duke University Press, 2008); Valerie Lambert, Choctaw Nation: A Story of American Indian Resurgence (Lincoln: University of Nebraska Press, 2009).

8. Although I wish he had been more circumspect in publishing it in the form that he did, Amos Wright has assisted students of Yuchi history in publishing a kind of greatest hits compilation of historical criticisms of the $\mathrm{Yu}$ chi. Understanding anti-Yuchi discourse in the colonial, early American, and more recent periods remains a historical project worthy of sustained work. A 
scholar taking up this project can begin with the sources gathered by Wright in his Historic Indian Towns in Alabama, $1540-1838$ (Tuscaloosa: University of Alabama Press, 2003), I7I. He writes:

The Uchee had a terrible reputation, probably deserved, based on some of the following comments. George Stiggins, a Natchez Indian, described them around I83I as being "more indolent, more thievish, more dissipated, and depraved in their morals" than any other tribe. They were settled on both Big and Little Uchee Creeks and were related to the Shawnee. "They were the most savage in the Creek nation, cling closely to their tongue and culture, not mixing with others. They only marry among their own."

For Stiggins's Yuchi comments, of which Wright is citing just a portion, see George Stiggins, Creek Indian History: A Historical Narrative of the Genealogy, Traditions, and Downfall of the Ispocoga or Creek Indian Tribe of Indians (Birmingham AL: Birmingham Public Library Press, I989), 3I-33. Wright goes on to provide additional critical commentary on the Yuchi from Creek elites Alexander McGillivray (in I787) and Alexander Cornells (in I83I) as well as from clergymen Bolzius (in 1734) and John Wesley (in 1737) and Indian agent Benjamin Hawkins (in I897).

This may be my only opportunity to record the understandably ironic feelings evoked among Yuchi Methodists - many of whom have been especially interested in the study of early Yuchi history - when they encounter the founder of their faith tradition speaking of their ancestors as people whom he believed to be "indeed hated by most and despis'd by all the nations, as well for their cowardice, and for out-lying all the Indians upon the continent." As Christians, the Yuchi Methodists are understanding people who practice a doctrine of forgiveness, but they also preach about the virtues of honest and modest speech. Wesley's tone suggests to me one reason why his missionary work among the Indians of Georgia ended in failure.

Wright's sources are John Walton Caughey, McGillivray of the Creeks (Norman: University of Oklahoma Press, 1938), I58; C. L. Grant, Letters, Journals and Writings of Benjamin Hawkins, vol. 2 (Savannah GA: Beehive Press, 1980), 518, 631; Trevor R. Reese, Our First Visit to America: Early Reports from the Colony of Georgia, I732-I740 (Savannah GA: Beehive Press, I974), 60 . For an additional historical account emphasizing thievery as a distinctly Yuchi quality, see Jones, Historical Sketch of Tomo-chi-chi, 45. The quotation from John Wesley derives from volume 3 of The Works of the Reverend John Wesley (New York: J. Emory and B. Waugh for the Methodist Episcopal 


\section{Introduction}

Church, I83I), 50. Wright's quotation of Wesley does not quite match that given in this source.

9. William Bartram, William Bartram on the Southeastern Indians, ed. Gregory A. Waselkov and Kathryn E. Holland Braund (Lincoln: University of Nebraska Press, I995), 90. Similarly, if we consult Thomas Foster's edition of Hawkins's writings, we learn that his views of the Yuchi were more complex than the brief quotation excerpted by Wright (see note 7) would suggest. Benjamin Hawkins, The Collected Works of Benjamin Hawkins, I796-I8Io, ed. H. Thomas Foster (Tuscaloosa: University of Alabama Press, 2003).

Io. I did bring my ethnographic experiences and ethnological studies to bear on a historical inquiry in Jason Baird Jackson, "A Yuchi War Dance in I736," European Review of Native American Studies I6 (2002): 27-33.

I I. For a historical consideration of Yuchi identity and political action, visà-vis Muscogee (Creek) understandings of Yuchi subordination during in the twentieth century, see Pamela Wallace, "Yuchi Social History since World War II: Political Symbolism in Ethnic Identity,” PhD diss., University of Oklahoma, I998, and Pamela S. Wallace, "Indian Claims Commission: Political Complexity and Contrasting Concepts of Identity," Ethnohistory 49 (2002): 743-67.

I2. Jackson, "A Yuchi War Dance in I736," 27; Jason Baird Jackson, "Introduction," in Ethnology of the Yuchi Indians by Frank G. Speck (Lincoln: University of Nebraska Press, 2004), v-xvi.

I3. The dangers common to scholarly treatments of resistance are taken up in Michael F. Brown, "On Resisting Resistance," American Anthropologist 98 (I996): 729-35. For persistence see Spicer, "Persistent Cultural Systems"; Spicer and Spicer, "The Nations of a State"; and George Pierre Castile and Gilbert Kushner, eds., Persistent Peoples: Cultural Enclaves in Perspective (Tucson: University of Arizona Press, I98I).

I4. For a discussion of the Yuchi literature and the dearth of works relative to those dealing with the Creek and other groups, see especially Jackson, "Introduction," vi.

I5. Joshua Piker, Okfuskee: A Creek Indian Town in Colonial America (Cambridge mA: Harvard University Press, 2004). For an additional town-level study set in the territory known as the Creek Nation, see Karl Langston Davis, "'Much of the Indian Appears': Adaptation and Persistence in a Creek Community, I783-I854," PhD diss., University of North Carolina, Chapel Hill, 2003.

I6. Jackson, “A Yuchi War Dance in I736," 27-32; John T. Juricek, “First Georgia Reports of the Yuchis, I733," Yuchi History Notes 7 (2004), http:// jasonbairdjackson.com/2010/I2/25/first-georgia-reports-of-yuchis-I733/, accessed December 24, 2010. 
I7. The key sources in the Crane-Swanton debate are Verner W. Crane, "An Historical Note on the Westo Indians," American Anthropologist 2 (I9I8): 33 I-37; Verner W. Crane, "Westo and Chisca," American Anthropologist 2 I (I9I9): 463-65; John R. Swanton, "Westo," in Handbook of American Indians, Bureau of American Ethnology Bulletin 30, part 2, ed. Frederick Webb Hodge (Washington DC: Government Printing Office, I9ro), 936; John R. Swanton, "Identity of the Westo Indians," American Anthropologist 2I (I9I9): 2I3-I6; and John R. Swanton, Early History of the Creek Indians and their Neighbors, Bureau of American Ethnology Bulletin 73 (Washington DC: Government Printing Office, I922). The later sources are John Juricek, “The Westo Indians," Ethnohistory I I (I964): I34-73; Eric E. Bowne, "The Rise and Fall of the Westo Indians: An Evaluation of the Documentary Evidence," Early Georgia 28 (2000): 56-78; and Eric E. Bowne, The Westo Indians: Slave Traders of the Early Colonial South (Tuscaloosa: University of Alabama Press, 2005).

I8. Wright, Historic Indian Towns in Alabama, I7I. Jackson, Yuchi Ceremonial Life, 19-27, 291.

I9. Alan Gallay, The Indian Slave Trade: The Rise of the English Empire in the American South, I670-I7I 7 (New Haven Ст: Yale University Press, 2002), 3I9. For a further discussion of the Chestowee incident, see Brett Riggs's contribution to this volume.

20. John Worth, "Chisca," in Handbook of North American Indians, vol. I4: Southeast, ed. Raymond D. Fogelson (Washington DC: Smithsonian Institution, 2004), I76-77; the sources that Worth cites in his Chisca essay are given here in the order in which he cites them: Swanton, Early History of the Creek Indians and their Neighbors, 288-308; John H. Hann, "Florida's Terra Incognita: West Florida's Natives in the Sixteenth and Seventeenth Century" Florida Anthropologist 4I (I988): 6I-I07; John H. Hann, A History of the Timucua Indians and Missions (Gainesville: University Press of Florida, I996), 238-40; John E. Worth, The Struggle for the Georgia Coast: An Eighteenth-Century Spanish Retrospective on Guale and Mocama, Anthropological Papers of the American Museum of Natural History, no. 75 (New York, I995), I5, I8, 52, 54; John E. Worth, The Timucuan Chiefdoms of Spanish Florida, 2 vols., vol. I: Assimilation, vol. II: Resistance and Destruction (Gainesville: University Press of Florida, 1998), 208; Charles Hudson, The Juan Pardo Expeditions: Explorations of the Carolinas and Tennessee, 1566-1568 (Washington DC: Smithsonian Institution Press, I990), 223-24, 270; J. Joseph Bauxar, "Yuchi Ethnoarchaeology, Part I: Some Yuchi Identifications Reconsidered.” Ethnohistory 4 (I957): 279-30I; J. Joseph Bauxar, Yuchi Ethnoarchaeology, Part II: The Yuchi of Tennessee, Part III: The Mouse Creek Focus, Part IV: Correlation 


\section{Introduction}

of Ethnohistorical and Archaeological Data, Part V: Conclusions" Ethnohistory 4 (I957): 369-464; William L. McDowell Jr., ed., Journals of the Commissioners of Indian Trade, September 20, I7Io-August 29, I7I8, The Colonial Records of South Carolina, series 2, vol. I (Columbia: South Carolina Archives Department, I955), 24, 53-57; John E. Worth, “The Lower Creeks: Origins and Early History," in Indians of the Greater Southeast: Historical Archaeology and Ethnohistory, ed. Bonnie G. McEwan (Gainesville: University Press of Florida, 2000), 267-98; Jackson, "Yuchi," 4I5-28; Bernard G. Hoffman, Observations on Certain Ancient Tribes of the Northern Appalachian Province, Bureau of American Ethnology Bulletin I9I (Washington DC: Government Printing Office, I964); William Greene, “The Erie/Westo Connection: Possible Evidence of Long Distance Migration in the Eastern Woodlands during the 16 th and 17 th Centuries," paper presented at the Southeastern Archaeological Conference, Greenville sc, I998; Bowne, The Westo.

2I. Other organizational schemes for this volume could have been devised and a different range of contributions could have been assembled. The theory motivating the choices reflected here can be described overtly. The volume reflects a desire to proceed in multidisciplinary fashion, with contributions from the fields of historical linguistics, history, historical anthropology, and archaeology. It also works from the assumption that in addition to regarding it for different temporal periods, Yuchi history is also effectively viewed (given the provisional state of its study) from the vantage point of the better known $\mathrm{Na}$ tive peoples with whom the Yuchi have had sustained contact. As is reflected in this volume, these are the Muscogee (Creek), Shawnee, Seminole, and Cherokee. As an ethnographer I can note that these four groups are also the $\mathrm{Na}$ tive peoples with whom the present-day Yuchi community maintains the closest relationships. It is important to stress that with the exception of the Yuchi story in the context of the Seminole Wars and associated Seminole removals, this volume does not take up the Yuchi story during the Removal era, including the time of the Creek Civil War that preceded it. Sources for the writing of such a history are available, and Yuchi removal is the crucial link connecting the colonial and early American period to post-removal history in Indian Territory and is thus a particularly pressing matter for historical investigation.

22. Jackson, Yuchi Ceremonial Life, passim, especially 206-40; Speck, Ethnology of the Yuchi Indians, I02-3I; Albert Gatschet, "Some Mythic Stories of the Yuchi Indians,” American Anthropologist 6 (I893): 279-82; Günter Wagner, Yuchi Tales (New York: G. E. Stechert and Company, I93I).

23. See Warren, this volume, and Greg Urban and Jason Baird Jackson, "Mythology and Folklore," in Handbook of North American Indians, vol. 
I4: Southeast, ed. Raymond D. Fogelson (Washington DC: Smithsonian Institution, 2004), 707-I9.

24. Lester Eugene Robbins, The Persistence of Traditional Religious Practices among Creek Indians, PhD diss., Southern Methodist University, I976, 5. Many Upper Creek towns continue, like the Yuchi, to maintain the institution of tribal town chieftainship and the practice of an annual ceremonial cycle in which the Green Corn Ceremony is the most important event. While I have written in this introduction of anti-Yuchi hostility expressed by Creek leaders, I also want to stress that the Yuchi have, in Oklahoma, long maintained close ties with numerous tradition-minded Creek towns, especially among the Upper Creek towns preserving Green Corn Ceremonialism. Visiting patterns between the Yuchi and these towns are discussed in Jackson, Yuchi Ceremonial Life, passim. There are also some contemporary Creek political leaders sympathetic to Yuchi concerns.

25. The link between the world's fate and Yuchi ritual obligations is discussed in various ethnographic sources and is articulated by Yuchi ceremonialists today. For an instance, see Speck, Ethnology of the Yuchi Indians, I07. As reflected by my pronoun usage here, there is some disagreement across time and individual narrators as to the gender of the Sun in Yuchi cosmology. Instability in the understood gender of the Creator is a theme in Shawnee ethnography as well. This matter is explored in the work of Carl F. Voegelin and Erminie Wheeler Voegelin, including their "The Shawnee Female Deity in Historical Perspective," American Anthropologist 46 (I944): 370-75. Voegelin and Voegelin specifically discuss the relationship between Shawnee beliefs and those of the Yuchi, Iroquois, and Christian Europeans with whom the Shawnee have been in sustained contact. 